\section{O FEMININO COMO POSSIBILIDADE DE NOVAS FORMAS DE SOCIABILIDADE}

\section{0 avesso do avesso: feminilidade e novas formas de subjetivação, de} Márcia Arán. Rio de Janeiro: Garamond, 2006, 226p.

\section{Isabel Fortes \\ Psicanalista; doutora em Teoria Psicanalítica pela UFRJ; professora colaboradora (com Bolsa de Fixação de Pesquisador da Faperj) do Programa de Pós-graduação em Teoria Psicanalítica do Instituto de Psicologia da UFRJ.}

Pensar o feminino constitui, sem dúvida alguma, um caminho para compreender o laço social na nossa cultura. Mais ainda: pensar o feminino conduz a concebermos a subjetivação como uma forma sempre provisória e passível de transformação: não eterna e não universal. É isso que podemos reafirmar depois da leitura de $\mathrm{O}$ avesso do avesso: feminilidade e novas formas de subjetivação, de Márcia Arán.

Logo no início do livro, é apresentada a proposta de analisar o feminino no encontro com a cultura, mostrando como uma cultura que compreende o feminino e o masculino como identidades fixas se constrói a partir de um sistema hierárquico de categorias binárias. A diferença entre os sexos na cultura ocidental ficou amarrada a uma organização simbólica na qual masculino e feminino estiveram sob o efeito de uma relação de dominação. É a partir da análise deste contexto do binarismo sexual que é lançada uma pergunta absolutamente fundamental: "Seria possível pensar a diferença fora do sistema sócio-simbólico da dominação masculina?"

Com efeito, outro lugar para a diferença entre os sexos se anuncia, trazendo consigo a possibilidade de novas formas de sociabilidade. A diferença que não fixa a identidade, mas, ao contrário, impõe um limite ao princípio de identidade, pode conduzir à experiência de um encontro que escapa à alternativa domínio-servidão.

Por outro lado, o feminino como o outro da cultura abala a equivalência que sempre se fez entre sujeito, masculino e razão, a ponto de podermos dizer, com Nietzsche, que o feminino exerce uma crítica imperiosa à idéia de razão. Se a construção da cultura ocidental se deu como correlata da construção da identidade masculina, introduzir o feminino na cultura conduz a uma transformação desta última.

Uma cultura feminina? A autora adverte: não adianta simplesmente substituirmos um binarismo por outro, no qual o feminino seria visto como superior. Trata-se, antes, de uma nova forma de pensar a alteridade, a partir da qual se afirma a ousada proposta de Arán: “A questão é como, no exercício da alteridade, não reproduzir o modelo masculino onde o outro - eternamente feminino — assume o lugar do objeto e o Um - masculino — se forja como universal." 
Este novo topos social que acolhe a feminilidade e transforma a relação entre os sexos já está sendo desenhado. O cenário que possibilita esta mudança é resumido em alguns pontos principais, que podem ser destrinchados pelo leitor: a crise da família nuclear, a entrada da mulher no mercado de trabalho, a separação da sexualidade da reprodução e a política de visibilidade da homossexualidade.

Aqui, uma leitura crítica da psicanálise é muito bem-vinda. Quando colocou o feminino circunscrito à questão fálica da castração e da inveja do pênis, a psicanálise tornou-se cúmplice de um projeto de civilização que se afirma pela exclusão da feminilidade. A autora vai demonstrar como a aposta freudiana na civilização se faz a partir de um distanciamento do feminino e de uma encarnação do masculino.

Ao retomar alguns textos clássicos sobre essa questão, o livro procura inserir Freud em uma tradição teórica que estabelece uma antinomia entre a mulher e a civilização, que está na origem mesmo da história do Ocidente. No entanto, em vez de apresentar uma versão crítica a esta antinomia, a teoria sexual na psicanálise, ao menos em Freud e Lacan, fundamenta a relação entre os sexos a partir da referência ao sexo masculino, "onde não existe propriamente uma diferença, mas sim pares de opostos que giram em torno da lógica fálica”. Enquanto na teoria freudiana o lugar oferecido à mulher é o de um sentimento e de uma posição de inferioridade, na teoria lacaniana, a mulher aparece como inacessível, inexistente, ou não simbolizável. Em ambos, o feminino é um déficit, uma negatividade.

Entretanto, Arán mostra como no avesso do avesso da teoria psicanalítica, ou seja, na dobra da teoria sobre ela mesma, podemos encontrar uma reflexão fecunda para pensar a singularidade do feminino. E, aqui, a autora desenvolve sua maneira original de analisar o feminino na psicanálise, ao indicar como podemos nos aproximar da feminilidade por meio da idéia de força pulsional, ou seja, de excesso, contingência e indeterminação. Tomando como eixos principais de referência as obras de Monique David-Ménard, Monique Schneider e Joel Birman, autores que vêm há muito tempo se debruçando sobre o tema da feminilidade, vemos ser desenhada uma nova cartografia para se pensar a diferença - segundo a qual será questionada a hegemonia do Édipo e da castração na psicanálise - , e deslinda-se a proposta de uma leitura crítica da metapsicologia da pulsão que se constitui ao mesmo tempo em uma metapsicologia da alteridade.

Se o feminino ficou como o Outro da civilização ocidental, e como tal foi excluído em nome do princípio de identidade, resgatá-lo como positividade inclui admitir o Outro como diferença, isto é, como o que oferece um limite à identidade. Neste sentido, é fundamental o olhar do psicanalista sobre o campo do excesso pulsional, pois é nele que encontramos uma forma de conceber a diferença que escapa ao verticalismo e à hierarquia. $\mathrm{Na}$ perspectiva destes enunciados, somos convidados a vislumbrar, como já mencionamos, novas formas de sociabilidade.

O avesso do avesso seria o indizível, o inacessível, ou, ao contrário, aquilo que é visível e palpável, mas do que, como bem anunciou Freud, relutamos em nos deixar aproximar? O livro de Arán nos leva a ficar com a segunda hipótese.

Recebida em 6/2/2007.

Aprovada em 25/2/2007.

Isabel Fortes

isafortes@bol.com.br 